\title{
Predictors of In-Hospital Mortality in Patients Admitted to the Emergency Department with Cardiogenic Pulmonary Edema
}

\section{Acil Servise Kardiyojenik Pulmoner Ödem ile Başvuran Hastalarda Hastane İçi Mortalitenin Belirleyicileri}

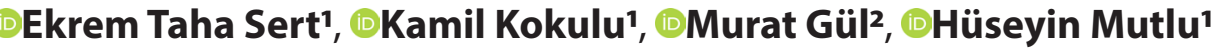 \\ 'Department of Emergency Medicine, Aksaray University Medical School, Aksaray, Turkey \\ 2 Department of Cardiology, Aksaray University Medical School, Aksaray, Turkey
}

\begin{abstract}
Background: Despite significant advances in the treatment of heart failure, the prognosis of acute cardiogenic pulmonary edema (ACPE) continues to be a serious problem. The objective of this study is to determine the risk factors affecting in-hospital mortality in patients with ACPE.

Material and Method: We enrolled 305 patients who were hospitalized with cardiogenic pulmonary edema as a diagnosis. Clinical, biochemical and echocardiographic variables were collected and analysed. The patients were divided into two groups according to the presence of mortality. Both groups were evaluated in terms of clinical features during admission to the emergency department (ED) and factors affecting in-hospital mortality.

Results: Forty-two patients died and the mortality rate was $13.8 \%$. To determine the factors affecting mortality, multiple logistic regression analysis was performed. In the regression analysis, it was seen that age at admission to the ED (OR:1.75, 95\% Cl 1.183.05, p:0.014), systolic blood pressure (OR:0.95, 95\% Cl 0.31-0.98, p:0.040), presence of acute myocardial infarction (OR:4.17, 95\% Cl 1.85-7.13, p:0.001), positive troponin (OR:5.47, 95\% Cl 1.077.46, p:0.011), atrial fibrillation rhythm (OR;3.16, 95\% Cl 1.81-8.02, $\mathrm{p}: 0.010)$, inotropic drug usage (OR;5.61, $95 \% \mathrm{Cl} 1.87-9.24, \mathrm{p}: 0.013)$ increased in-hospital mortality.
\end{abstract}

Conclusion: Our findings could help clinicians in identifying patients with poor prognosis early in the presence of identified risk factors.

Keywords: Cardiogenic pulmonary edema, mortality, emergency department, clinical presentation
Öz

Amaç: Kalp yetmezliği tedavisindeki önemli ilerlemelere rağmen akut kardiyojenik pulmoner ödemin (AKPÖ) prognozu ciddi bir sorun olmaya devam etmektedir. Bu çalışmanın amacı, ACPE gelişen hastalarda hastane içi mortaliteyi etkileyen risk faktörlerini belirlemektir.

Gereç ve Yöntem: Çalışmamıza AKPÖ nedeniyle hastaneye yatırılan 305 hastayı dahil ettik. Klinik, biyokimyasal ve ekokardiyografik bulgular analiz edildi. Hastalar, mortalite varlığına göre iki gruba ayrıldı. Her iki grup acil servise (AS) başvurudaki klinik özellikler ve hastane içi mortaliteye etki eden faktörler açısından değerlendirildi.

Bulgular: Hastaların \%13.8'i hayatını kaybetti. Mortaliteye etki eden faktörleri belirlemek için çoklu lojistik regresyon analizi yapıldı. Yapılan regresyon analizinde, AS'ye kabulündeki yaş (OR:1.75, \%95 Cl 1.18-3.05, p:0.014), sistolik kan basıncı (OR: 0.95, \%95 Cl 0.31-0.98, p:0.040), akut miyokard infarktüsü varlığı OR:4.17, \%95 Cl 1.85-7.13, p:0.001), pozitif troponin (OR:5.47, \%95Cl 1.07-7.46, p:0.011), atriyal fibrilasyon (OR;3.16, \%95 Cl 1.81-8.02, p: 0.010), inotropik ilaç kullanımının (OR;5.61, \%95 Cl 1.87-9.24, p: 0.013) hastane içi mortaliteyi arttırdığı görüldü.

Sonuç: Bulgularımız, tanımlanan risk faktörlerinin varlığında, klinisyenlerin kötü prognoza sahip olacak hastaları erken dönemde tanımlamasına yardımcı olabilir.

Anahtar Kelimeler: Kardiyojenik pulmoner ödem, mortalite, acil servis, klinik tablo

Corresponding (İletişim): Ekrem Taha Sert, Aksaray Üniversitesi Tıp Fakültesi Dekanlığı Adana Yolu Üzeri E-90 Karayolu 7. Km Merkez, Aksaray, Türkiye

E-mail (E-posta): tahaekrem@hotmail.com

Received (Geliş Tarihi): 04.01.2021 Accepted (Kabul Tarihi): 01.02.2021 


\section{INTRODUCTION}

Acute pulmonary edema (APE) is one of the important clinical problems in patients admitted to emergency department (ED). Most patients in the emergency setting with pulmonary edema have the acute cardiogenic variety, resulting mainly from elevated left ventricle (LV) end-diastolic pressure. Acute cardiogenic pulmonary edema (ACPE), which is a subset of $A P E$, is a common symptom of acute heart failure and often results in acute decompensated heart failure (ADHF). [1] In the United States, approximately 1 million patients are hospitalized annually due to ADHF, and its mortality rate is $4 \%$ according to the data. ${ }^{[2]}$ Samsky et al ${ }^{[3]}$ analyzed heart failure mortality and readmission rates between 2005 and 2015. They detected that in the United States, $3.8 \%$ of patients admitted with heart failure died during hospitalization, and the rate of readmission was $19.9 \%$.

In general, ACPE emerges suddenly with a dramatic clinical picture and is associated with poor in-hospital outcomes. ACPE is one of the common causes of acute respiratory failure. The primary objective in patients with ACPE is to provide adequate tissue oxygenation to prevent the development of organ dysfunction and multiple organ failure. Although rapid recovery is achieved in many patients with standard medical therapy such as vasodilators, diuretics, inotropic agents and supplemental oxygen therapy, a group of patients do not respond to these and develop hypoxemic respiratory failure. These patients need intensive care due to accompanying hypercapnia and respiratory acidosis. The objective of this study is to determine the risk factors affecting in-hospital mortality in patients with ACPE.

\section{MATERIALS AND METHODS}

\section{Patient selection}

In this study, the data of the patients aged 18 years and older, who were diagnosed with ACPE in tertiary ED in our hospital and hospitalized between January 1, 2017 and December 31, 2019, were analyzed. The data of the study were obtained from the hospital electronic database. Local ethics committee approval was obtained for the study (Ethics committee number: 2019/12-20).

The patients, whose records could not be completely reached, who were transferred to another hospital, who had severe respiratory distress caused by conditions other than ACPE (for example, pneumonia, severe anemia, renal failure), who were exposed to chemicals (for example, ammonia), who were pregnant, who had inflammatory and neoplastic disease, who underwent cardiopulmonary resuscitation and who were under 18 years of age, were excluded from the study.

\section{Data collection and processing}

The patients' demographiccharacteristics, vital signs at the time of admission to ED, physical examination findings, complaints at the time of admission, chronic diseases, chest X-ray and/or computed tomography (CT) findings, electrocardiogram (ECG) findings, transthoracic echocardiographic (ECHO) findings, laboratory results, mechanical ventilation (MV) requirement, intensive care need, length of hospital stay and in-hospital mortality rates were recorded. ECG, ECHO, radiological imaging and laboratory tests were performed in all patients following their admissions to ED. ECHO was performed by a cardiologist.

As the initial treatment procedure in the ED, the patients were treated with oxygen therapy, intravenous (IV) morphine sulfate and IV furosemide were administered, and IV nitroglycerine infusion was performed. Hypotension was initially treated with dobutamine and/or noradrenaline. While noninvasive ventilation support was provided to the patients with persistent respiratory failure, intubation and MV were used in refractory hypoventilation cases. Angiotensin-converting enzyme inhibitors or angiotensin receptor antagonists and beta blockers were added to the treatment in the subacute phase of the disease.

The patients were divided into two groups according to the presence of mortality. Both groups were evaluated in terms of clinical features during admission to ED and factors affecting in-hospital mortality.

\section{Definition and Diagnosis}

ACPE was defined as the presence of pulmonary alveolar/ interstitial congestion on chest X-ray and/or CT with at least two of the followings: 1 ) severe respiratory distress or worsening respiratory distress or persistent severe dyspnea, orthopnea 2) rales in lungs 3 ) high jugular venous pressure. ${ }^{[4]}$

Diagnosis of acute myocardial infarction (AMI) was established according to the criteria set by the European Society of Cardiology guidelines. ${ }^{[5]}$ Vascular lesions detected in the coronary angiography of the patients were recorded. The presence of a lesion causing $50 \%$ or more stenosis in any coronary artery was recorded as significant stenosis. Hypertension was defined as systolic blood pressure $>140$ $\mathrm{mmHg}$ and/or diastolic blood pressure $>90 \mathrm{mmHg}$, or antihypertensive drug use.

ECHO procedure was performed from parasternal and apical windows with two-dimensional, $M$ mode, color doppler, pulsed wave doppler and tissue doppler imaging techniques. ECHO measurements were performed based on the criteria recommended by the American Society of Echocardiography. ${ }^{[6]}$

\section{Outcome measures}

The primary outcome measure was mortality rate of the patients admitted to the hospital from ED. This was used to determine the in-hospital mortality rate of the hospitalized patients. The secondary outcome was the effectiveness of clinical features during admission to ED on in-hospital mortality. Thus, the risk factors affecting mortality rate in patients with ACPE were determined. 


\section{Statistical Analysis}

Statistical analysis was performed using the Statistical Package for Social Sciences (SPSS) for Windows 20 (IBM SPSS Inc., Chicago, IL). While evaluating the study data, descriptive statistical methods (percentage calculations, median, mean and standard deviation) were calculated. Continuous variables were expressed as mean \pm standard deviation (SD), while categorical variables were expressed as percentage. Normal distribution of the data was evaluated with KolmogorovSmirnov test. Student's t-test was used for the comparison of normally distributed continuous variables, while MannWhitney U-test was used for the comparison of non-normally distributed variables. Pearson's Chi-square or Fisher's test was used to compare the categorical variables. Univariate and multivariate logistic regression analysis was performed to determine the relationship between in-hospital mortality rate and possible clinical variables. Multivariate logistic regression analysis was applied to the variables with $p<0.1$ in univariate logistic regression analysis. Odds ratios and $95 \%$ confidence intervals were used to predict the relationship between independent determinants of hospital mortality rate. A value of $p<0.05$ was considered significant in all comparisons.

\section{RESULTS}

305 patients were included in our study. The mean age of the patients was $67 \pm 5$ years; $57.4 \%(n=175)$ were male, and $42.6 \%$ $(n=130)$ were female. Demographic and clinical characteristics of the patients are given in Table 1. In terms of vital signs, while there was no statistical difference between the two groups in terms of heart rate, oxygen saturation and body temperature, there was a statistically significant difference in terms of systolic blood pressure $(p<0.05)$. The most common accompanying comorbidities were determined as congestive heart failure and hypertension $(76.4 \%$ and $64.9 \%$, respectively). The patients, who died, had lower LV EF compared to the survivors (p: 0.001). ECG and ECHO findings of the patients, who died and survived, are shown in Table 2. Noninvasive MV was needed in $69.2 \%$ of the patients $(n=211)$. Endotracheal intubation was needed in 98 (32.1\%) patients. The mean follow-up period of the patients who survived was $5 \pm 4$ days, while the mean follow-up period of those who died was $9 \pm 5$ days.

Forty-two (13.8\%) patients died. When the patients, who died and survived, were compared; age, systolic blood pressure, atrial fibrillation/flutter, high troponin level, EF, moderate-severe mitral insufficiency and inotropic drug usage were found to be statistically significant. To determine the factors affecting mortality, multiple logistic regression analysis was performed (Table 3). In the regression analysis, it was seen that age at admission to the ED (OR:1.75, 95\% Cl 1.18-3.05, p:0.014), systolic blood pressure (OR:0.95, 95\% Cl 0.31-0.98, p:0.040), presence of AMI (OR:4.17, 95\% Cl 1.85-7.13, p:0.001), elevated troponin levels (OR:5.47, 95\% Cl 1.07-7.46, p:0.011), atrial fibrillation rhythm (OR;3.16,95\% Cl 1.81-8.02, p:0.010), inotropic drug usage (OR;5.61, $95 \% \mathrm{Cl} 1.87-9.24, \mathrm{p}: 0.013)$ increased in-hospital mortality.
Table 1. Demographic and clinical characteristics of patients with ACPE and survival status

\begin{tabular}{lccc} 
& $\begin{array}{c}\text { Survivors } \\
(\mathbf{n = 2 6 3})\end{array}$ & $\begin{array}{c}\text { Nonsurvivors } \\
(\mathbf{n = 4 2 )}\end{array}$ & p value \\
\hline Age, years & $66.7 \pm 5.5$ & $70.6 \pm 4.9$ & $<0.001$ \\
Sex, Female & $115(43.7 \%)$ & $15(35.7 \%)$ & 0.330 \\
$\begin{array}{l}\text { Admission vital signs } \\
\text { Body temperature }\left({ }^{\circ} \mathrm{C}\right)\end{array}$ & $36.8(36.7-37.0)$ & $36.9(36.6-37.1)$ & 0.658 \\
$\begin{array}{l}\text { Heart rate (beats/min) } \\
\begin{array}{l}\text { Systolic blood pressure } \\
\text { (mmHg) }\end{array}\end{array}$ & $117 \pm 31$ & $109 \pm 26$ & 0.069 \\
$\begin{array}{l}\text { Diastolic blood pressure } \\
\text { (mmHg) }\end{array}$ & $150 \pm 34$ & $132 \pm 39$ & 0.006 \\
$\begin{array}{l}\text { Oxygen saturation }(\%) \\
\text { Cardiovascular co-morbidities }\end{array}$ & $93 \pm 19$ & $87 \pm 18$ & 0.065 \\
\hline
\end{tabular}

Cardiovascular co-morbidities

\begin{tabular}{|c|c|c|c|}
\hline Hypertension & $167(63.7 \%)$ & $31(73.8 \%)$ & 0.193 \\
\hline Diabetes mellitus & $84(31.1 \%)$ & $18(42.9 \%)$ & 0.164 \\
\hline $\begin{array}{l}\text { Chronic atrial fibrillation/ } \\
\text { flutter }\end{array}$ & $59(22.4 \%)$ & $19(45.2 \%)$ & 0.002 \\
\hline Coronary artery disease & $110(41.8 \%)$ & $23(54.8 \%)$ & 0.155 \\
\hline Congestive heart failure & $203(77.2 \%)$ & $30(71.4 \%)$ & 0.415 \\
\hline Heart valve disease & $92(35.0 \%)$ & $14(33.3 \%)$ & 0.835 \\
\hline Peripheral vascular disease & $38(14.4 \%)$ & $5(11.9 \%)$ & 0.660 \\
\hline Dyslipidaemia & $20(7.6 \%)$ & $4(9.5 \%)$ & 0.427 \\
\hline $\begin{array}{l}\text { Previous acute pulmonary } \\
\text { edema }\end{array}$ & $37(14.1 \%)$ & $8(19.0 \%)$ & 0.398 \\
\hline Acute myocardial infarction & $20(7.6 \%)$ & $9(21.4 \%)$ & 0.005 \\
\hline \multicolumn{4}{|l|}{ Initial laboratory values } \\
\hline Glucose (mg/dL) & $241 \pm 131$ & $234 \pm 138$ & 0.846 \\
\hline Hemoglobin (g/dL) & $13.2 \pm 2.2$ & $12.1 \pm 2.4$ & 0.822 \\
\hline Sodium (mmol/L) & $137.9 \pm 4.7$ & $135.6 \pm 4.3$ & 0.105 \\
\hline Potassium (mmol/L) & $4.3 \pm 0.7$ & $4.4 \pm 0.6$ & 0.326 \\
\hline Creatinine (mg/dL) & $1.8 \pm 1.3$ & $2.0 \pm 1.4$ & 0.112 \\
\hline Urea (mg/dL) & $71 \pm 57$ & $81 \pm 46$ & 0.087 \\
\hline AST (U/L) & $20 \pm 15$ & $25 \pm 16$ & 0.610 \\
\hline $\operatorname{ALT}(\mathrm{U} / \mathrm{L})$ & $14 \pm 8$ & $18 \pm 7$ & 0.772 \\
\hline Albumin (g/dL) & $3.2 \pm 0.6$ & $3.0 \pm 0.5$ & 0.784 \\
\hline C-reactive protein (mg/dL) & $17 \pm 12$ & $12 \pm 8$ & 0.536 \\
\hline Positive troponin & $33(12.5 \%)$ & $14(33.3 \%)$ & 0.001 \\
\hline BNP elevated, $(n=116)$ & $101(38.3 \%)$ & $15(35.7 \%)$ & 0.765 \\
\hline Arterial blood pH & $7.2 \pm 0.20$ & $7.2 \pm 0.18$ & 0.981 \\
\hline $\begin{array}{l}\text { Arterial blood lactate } \\
\text { (mmol/L) }\end{array}$ & $5.6 \pm 3.2$ & $6.0 \pm 2.9$ & 0.493 \\
\hline
\end{tabular}

\begin{tabular}{|c|c|c|c|}
\hline In-hospital mortality & OR & $95 \% \mathrm{Cl}$ & p value \\
\hline Age & 1.75 & $1.18-3.05$ & 0.014 \\
\hline Systolic blood pressure & 0.95 & $0.31-0.98$ & 0.040 \\
\hline Atrial fibrillation rhythm & 3.16 & $1.81-8.02$ & 0.010 \\
\hline Positive troponin & 5.47 & $1.07-7.46$ & 0.011 \\
\hline Ejection fraction & 1.04 & $0.65-3.52$ & 0.063 \\
\hline Acute myocardial infarction & 4.17 & $1.85-7.13$ & 0.001 \\
\hline Moderate-severe mitral insufficiency & 3.32 & $1.79-6.14$ & 0.272 \\
\hline Inotropic drug usage & 5.61 & $1.87-9.24$ & 0.013 \\
\hline
\end{tabular}




\begin{tabular}{|c|c|c|c|}
\hline & $\begin{array}{l}\text { Survivors } \\
(n=263)\end{array}$ & $\begin{array}{c}\text { Nonsurvivors } \\
(n=42)\end{array}$ & $\begin{array}{c}\mathbf{p} \\
\text { value }\end{array}$ \\
\hline \multicolumn{4}{|l|}{ Electrocardiography findings } \\
\hline Atrial fibrillation & $66(25.1 \%)$ & 20 (47.6\%) & 0.003 \\
\hline Left bundle branch block & $78(29.7 \%)$ & $12(28.6 \%)$ & 0.886 \\
\hline Right bundle branch block & $52(19.8 \%)$ & $7(16.7 \%)$ & 0.636 \\
\hline ST-segment elevation & $5(1.9 \%)$ & $2(4.8 \%)$ & 0.248 \\
\hline ST-segment depression & $21(8.0 \%)$ & $6(14.3 \%)$ & 0.182 \\
\hline T-wave inversion & $30(11.4 \%)$ & $8(19.0 \%)$ & 0.164 \\
\hline \multicolumn{4}{|l|}{ Echocardiography findings } \\
\hline Ejection fraction & $44 \pm 8$ & $39 \pm 7$ & 0.001 \\
\hline Moderate-severe aortic stenosis & $9(3.4 \%)$ & $3(7.1 \%)$ & 0.249 \\
\hline Moderate-severe aortic insufficiency & $6(2.3 \%)$ & $2(4.8 \%)$ & 0.304 \\
\hline Moderate-severe mitral stenosis & $1(0.4 \%)$ & 0 & 0.689 \\
\hline Moderate-severe mitral insufficiency & $21(8.0 \%)$ & $9(21.4 \%)$ & 0.007 \\
\hline Inotropic drug usage & $23(8.7 \%)$ & $14(33.3 \%)$ & $<0.001$ \\
\hline Non-invasive MV at ED & $180(68.4 \%)$ & $31(73.8 \%)$ & 0.484 \\
\hline Endotracheal intubation at ED & 80 (30.4\%) & $18(42.9 \%)$ & 0.109 \\
\hline \multicolumn{4}{|l|}{ Procedures } \\
\hline Coronary angiography & $21(8.0 \%)$ & $9(21.4 \%)$ & 0.012 \\
\hline Non-significant CAD & $10(3.8 \%)$ & $3(7.1 \%)$ & 0.320 \\
\hline Single-vessel CAD & $2(0.8 \%)$ & 0 & 0.743 \\
\hline Double-vessel CAD & $3(1.1 \%)$ & $2(4.8 \%)$ & 0.093 \\
\hline Three-vessel CAD & $6(2.3 \%)$ & $4(9.3 \%)$ & 0.087 \\
\hline \multicolumn{4}{|l|}{ Outcome } \\
\hline Days of hospitalization & $5 \pm 4$ & $9 \pm 5$ & 0.543 \\
\hline ICU admission & $164(62.3 \%)$ & $36(85.7 \%)$ & $<0.001$ \\
\hline ICU mortality & & 29 (69.1\%) & \\
\hline mortality & & $13(30.9 \%)$ & \\
\hline
\end{tabular}

Data are expressed as mean \pm standard deviation (SD), as number (percentage), ICU: Intensive care unit, MV: mechanical ventilation, ED: emergency department, $C A D:$ coronary artery disease

\section{DISCUSSION}

Despite significant advances in the treatment of heart failure, the prognosis of ACPE continues to be a serious problem. Although acute treatment of ACPE is similar in different heart diseases, diagnosis and treatment strategies can differ significantly. Therefore, it is important to evaluate the risk factors that will affect the early and late prognosis of the patient in determining the best treatment strategy for the patients who recovered from the acute event. In our study, we found the in-hospital mortality rate as $13.8 \%$ following ACPE development. We determined that advanced age, systolic blood pressure at admission, elevated troponin levels, $\mathrm{AMI}$, atrial fibrillation rhythm and inotropic drug need were associated with in-hospital mortality. These findings suggest that specific clinical picture pattern plays an important role in terms of predicting mortality.

Acute heart failure, which includes different clinical conditions such as acute decompensation of chronic heart failure, right ventricular failure, cardiogenic shock, and APE, is associated with increased mortality rates and hospitalization..$^{[7,8]}$ In acute heart failure, in-hospital mortality rate is 4-7\%, 3-month mortality rate after discharge is $7-11 \%$, and readmission rate in the first 3 months is around $25-30 \%$. ${ }^{[9]}$ Previous studies revealed that advanced age, severe LV dysfunction, acute coronary syndromes, blood pressure at admission, presence of renal failure, inotropic drug need and anemia were the main determinants of mortality. ${ }^{[10,12]}$ In-hospital mortality in ADHF was found to be associated with advanced age, high heart rate, hyponatremia, hypotension, LV systolic dysfunction, increased blood urea nitrogen level, creatinine, troponin or natriuretic peptides. ${ }^{[13,14]}$ Fonarow et al. ${ }^{[15]}$ developed a risk score for in-hospital mortality in patients hospitalized due to acute heart failure. In this study, they found that age, systolic blood pressure, blood urea nitrogen level and heart rate were independent predictors of mortality. Similarly, our study revealed that age, admission systolic blood pressure, positive troponin and the need for inotropic agents were associated with in-hospital mortality. Moreover, we observed that atrial fibrillation rhythm was an additional strong predictor which had not been previously reported.

Most commonly, ACPE occurs with acute myocardial ischemia or infarction, cardiomyopathy, valvular heart disease or hypertensive emergencies. AMI is the most common cause of heart failure and pulmonary edema. Myocardial muscle damage results in low cardiac reserve and an increase in LV diastolic, venous and pulmonary capillary pressure. This results in fluid extravasation into the interstitial and alveolar space. ACPE constitutes 10-20\% of acute heart failure syndromes, and mortality may be higher especially when associated with AMI. $[16,17]$ While the majority of the patients admitted with ACPE had normal or high systolic blood pressure, only 5-8\% of them were admitted with low systolic blood pressure ( $<90 \mathrm{mmHg}$ ). If hypoperfusion findings accompany, this group has a poor prognosis. ${ }^{[18]}$ In our study, certain traditional cardiovascular risk factors in the general population such as coexisting dyslipidemia and hypertension were not associated with mortality. In contrast, atrial fibrillation was associated with mortality in multivariate analysis. We found AMI in 9.5\% (29) of the patients admitted with ACPE. We found the mortality rate as $21.4 \%$ in the patients with AMI. The relationship between $\mathrm{AMI}$ and high mortality rates in the patients admitted with ACPE may be caused by severe LV systolic dysfunction. Early diagnosis and treatment by evaluating the previous or concomitant cardiovascular disease, ECG and ECHO findings in these patients may help reduce in-hospital mortality.

It was revealed that noninvasive MV application in the treatment of acute cardiogenic pulmonary edema reduced the need for endotracheal intubation and mortality. ${ }^{[19-22]}$ In a meta-analysis where standard oxygen therapy and noninvasive MV applications in the patients with cardiogenic pulmonary edema were compared, hospital mortality and intubation rates were significantly lower in the noninvasive MV group compared to standard therapy group. ${ }^{[21,22]}$ In our study, similar to other studies, there was no significant difference in mortality in the patients who received noninvasive MV in ED.

This study has some limitations. The first limitation of the study was the limited number of subjects fulfilling the inclusion criteria. Secondly, the study is retrospective. The retrospective 
nature of the study restricted data to those routinely collected. Our retrospective study design may be related to selection biases, because this study only included patients admitted to the hospital. Third, the study is single-centered. The singlecenter study design carries inherent risks of bias.

\section{CONCLUSION}

$A C P E$ is a common condition in the ED and one of the most common causes of hospitalization. We determined that age, systolic blood pressure at admission, elevated troponin levels, AMI diagnosis, atrial fibrillation rhythm and inotropic drug need were associated with in-hospital mortality in the patients admitted with ACPE. Our findings could help clinicians in identifying patients with poor prognosis early in the presence of identified risk factors.

\section{ETHICAL DECLARATIONS}

Ethics Comittee Approval: Aksaray University School of Medicine, Aksaray Education and Research Hospital Scientific Research Evaluation Committee approval was obtained for this study (approval number: 2019/12-20).

Conflict of Interest Statement: No conflict of interest was declared by the authors.

Financial Disclosure: The authors declared that this study has received no financial support.

\section{REFERENCES}

1. Ezekowitz JA, Bakal J, Kaul P, Westerhout C, Armstrong P. Acute heart failure in the emergency department: short and long-term outcomes of elderly patients with heart failure. Eur J Heart Fail 2008;10:308-314.

2. Gheorghiade M, Filippatos G, De Luca L, Burnett J. Congestion in acute heart failure syndromes: an essential target of evaluation and treatment. Am J Med. 2006;119(12 Suppl 1):S3-S10.

3. Samsky MD, Ambrosy AP, Youngson E, et al. Trends in readmissions and length of stay for patients hospitalized with heart failure in Canada and the United States. JAMA Cardiol. 2019;4(5):444-453.

4. Llorens $P$, Javaloyes $P$, Masip J, et al. Prognostic value of chest radiographs in patients with acute heart failure: The Radiology in Acute Heart Failure (RAD-ICA) study. Emergencias. 2019;31(5):318-326.

5. Roffi M, Patrono C, Collet JP, et al. 2015 ESC Guidelines for the management of acute coronary syndromes in patients presenting without persistent ST-segment elevation: Task Force for the Management of Acute Coronary Syndromes in Patients Presenting without Persistent ST-Segment Elevation of the European Society of Cardiology (ESC). Eur Heart J 2016;37(3):267-315.

6. Douglas PS, DeCara JM, Devereux RB, et al. Echocardiographic imaging in clinical trials: American Society of Echocardiography Standards for echocardiography core laboratories: Endorsed by the American College of Cardiology Foundation. American Society of Echocardiography Standards; American College of Cardiology Foundation. J Am Soc Echocardiogr. 2009;22(7):755-65.

7. Maggioni AP, Dahlström U, Filippatos G, et al. EURObservational Research Programme: regional differences and 1-year follow-up results of the Heart Failure Pilot Survey (ESC-HF Pilot). Eur J Heart Fail 2013;15(7):808-17.

8. Gheorghiade M, Abraham WT, Albert NM, et al. Systolic blood pressure at admission, clinical characteristics, and outcomes in patients hospitalized with acute heart failure. JAMA 2006;296(18):2217-26.
9. Farmakis D, Parissis J, Filippatos G. Acute heart failure: epidemiology, classification and pathophysiology. The ESC textbook of intensive and acute cardiovascular care. Oxford University Press, 2nd ed. 2015:459-469.

10. Parissis JT, Nikolaou M, Mebazaa A, et al. Acute pulmonary oedema: clinical characteristics, prognostic factors, and in-hospital management. Eur J Heart Fail 2010;12(11):1193-202.

11. Attias D, Mansencal N, Auvert B, et al. Prevalence, characteristics, and outcomes of patients presenting with cardiogenic unilateral pulmonary edema. Circulation 2010;122(11):1109-15.

12. Gray A, Goodacre S, Nicholl J, et al. The development of a simple risk score to predict early outcome in severe acute acidotic cardiogenic pulmonary edema: the 3CPO score. Circ Heart Fail 2010;3(1):111-7.

13. Fonarow GC. Clinical risk prediction tools in patients hospitalized with heart failure. Rev Cardiovasc Med 2012;13(1):e14-23.

14. Sridharan L, Klein L. Prognostic factors in patients hospitalized for heart failure. Curr Heart Fail Rep 2013;10(4):380-6.

15. Fonarow GC, Adams KF Jr, Abraham WT, Yancy CW, Boscardin WJ; ADHERE Scientific Advisory Committee Study Group and Investigators. Risk stratification for in-hospital mortality in acutely decompensated heart failure: classification and regression tree analysis. JAMA 2005;293(5):57280.

16. Nieminen MS, Brutsaert D, Dickstein K, et al. EuroHeart Failure Survey II (EHFS II): a survey on hospitalized acute heart failure patients: description of population. Eur Heart J 2006;27(22):2725-36.

17. Girou E, Brun-Buisson C, Taillé S, Lemaire F, Brochard L. Secular trends in nosocomial infections and mortality associated with noninvasive ventilation in patients with exacerbation of COPD and pulmonary edema. JAMA 2003;290(22):2985-91.

18. Nohria A, Tsang SW, Fang JC, et al. Clinical assessment identifies hemodynamic profiles that predict outcomes in patients admitted with heart failure. J Am Coll Cardiol 2003;41(10):1797-804.

19. Agarwal R, Aggarwal AN, Gupta D. Is noninvasive pressure support ventilation as effective and safe as continuous positive airway pressure in cardiogenic pulmonary oedema? Singapore Med J 2009;50(6):595-603.

20. Teke T, Feyzioglu B, Tosun M, Dogan M, Yesildag K, Ozdemir M. The role of torque teno virus (TTV) viremia in sarcoidosis etiology. Kuwait Medical Journal 2019;51(2):157-162.

21. Winck JC, Azevedo LF, Costa-Pereira A, Antonelli M, Wyatt JC. Efficacy and safety of non-invasive ventilation in the treatment of acute cardiogenic pulmonary edema-a systematic review and meta-analysis. Crit Care 2006;10(2):R69.

22. Masip J, Roque M, Sánchez B, Fernández R, Subirana M, Expósito JA. Noninvasive ventilation in acute cardiogenic pulmonary edema: systematic review and meta-analysis. JAMA 2005;294(24):3124-30. 